\title{
Cold-hardiness of silver sagebrush seedlings
}

\author{
JUNQIANG HOU AND J.T. ROMO
}

Authors are post-doctoral fellow and professor, Dept. of Plant Sciences, Univ. of Saskatchewan, 51 Campus Drive, Saskatoon, Sask. S7N 5A8.

\begin{abstract}
Silver sagebrush (Artemisia cana Pursh), a common shrub on Northern Mixed Prairie in Canada, is an excellent species to consider for ecological restoration. On the Canadian Prairies, freezing temperatures can occur during April and early May, months when most silver sagebrush seedlings emerge. Decreasing temperatures in autumn or exposure to freezing temperatures through winter may also be lethal to seedlings of this long-lived shrub. The purpose of this study was to characterize freezing tolerance in silver sagebrush seedlings because low temperatures may reduce establishment. Seedlings were grown from 1 week to 1 full growing season, exposed to freezing temperatures under controlled conditions, and lethal temperatures for 50 and $95 \%$ mortality (LT $\mathrm{T}_{50}$ and $\mathrm{LT}_{95}$ ) were determined. Averaged across 1- to 6-weekold seedlings, $\mathrm{LT}_{50}$ and $L \mathrm{~T}_{95}$ were -7.7 and $-11.1^{\circ} \mathrm{C}$, respectively. Changes in mortality with temperature variations were more gradual in younger than older seedlings, and mean $\mathbf{L T}_{95}$ was 2.8.$^{\circ} \mathrm{C}$ lower in 1- and 2-week than 4- and 6-week-old seedlings. Within age groups, death after freezing was greater in non-acclimated than acclimated seedlings. Virtually no non-acclimated seedlings survived $-14^{\circ} \mathrm{C}$, while mortality of acclimated seedlings was nearly nil in most cases. Only 6.9\% (SE $=5.5$ ) of seedlings grown under field conditions died in November after exposure to $-39^{\circ} \mathrm{C}$. Freezing tolerance of field-grown seedlings remained high over winter; seedling mortality after exposure to -39 and $-45^{\circ} \mathrm{C}$ averaged $5.6 \%$ ( $\mathrm{SE}=4.1$ ) in March. No seedlings survived temperatures lower than $-15^{\circ} \mathrm{C}$ in April, and predicted $\mathrm{LT}_{50}$ and $\mathrm{LT}_{95}$ averaged -15.6 and $-19.3^{\circ} \mathrm{C}$, respectively. Increased mortality after freezing in April indicates seedlings de-acclimated as temperatures rose and day length increased in spring. Since the potential of developing freezing tolerance is greater in older than younger seedlings, silver sagebrush seedlings that germinate early in growing season may survive the winter better than those germinating later. Under normal circumstances, temperatures on the Canadian Prairies should not threaten survival of silver sagebrush seedlings during their first winter.
\end{abstract}

Key Words: acclimation, Artemisia cana Pursh., freezing tolerance, Northern Great Plains, Mixed Prairie, preconditioning, restoration, seedbed ecology, seedling vigor.

Sagebrush (Artemisia) taxa are widely distributed on Northern Mixed Prairie (Coupland 1950, White and Currie 1983), but are considered undesirable in some areas because they may reduce

\footnotetext{
Funding for this research provided by research grants to JTR from the CanadaSaskatchewan Agriculture Green Plan, Saskatchewan Agriculture Development Fund, and Ducks Unlimited Canada.

Manuscript accepted 20 Jan 1998
}

production of associated grasses and forbs (White and Currie 1983, Young and Evans 1989). Sagebrush, however, is an important component of prairie ecosystems (Howard et al. 1976). Silver sagebrush (Artemisia cana Pursh) is palatable, providing browse for wild animals (Clarke 1930, Mitchell and Smoliak 1971, Barrett 1979). Silver sagebrush contributes to the structural diversity of prairie, and like other shrubs, provides cover for small animals, and improves snow accumulation and water infiltration (Howard et al. 1976, Young and Evans 1989, Pyke and Archer 1991).

Northern Mixed Prairie in Canada is characterized by a short growing season and severe, cold winters (Coupland 1950). Plants in this region must adapt to unseasonable frost and extremely low temperatures (Gusta and Chen 1987). Adult sagebrush plants apparently can withstand very low temperatures (Walser et al. 1990), but information on freezing tolerance of silver sagebrush seedlings is not available. Silver sagebrush is widespread on Northern Mixed Prairie in Canada (Coupland 1950, Mitchell and Smoliak 1971), and is an excellent species to consider for ecological restoration. The ability to cope with freezing temperatures in young seedlings might be different because freezing tolerance in plants changes with plant age and varying environmental conditions (Gusta and Chen 1987, Hou and Romo 1997). The purpose of this study was to determine freezing tolerance in silver sagebrush seedlings because freezing temperatures may limit establishment of this shrub. Cold-hardiness of silver sagebrush seedlings grown in containers for 1 week to 1 full growing season was determined.

\section{Materials and Methods}

\section{Seed Collection}

Silver sagebrush seeds (achenes) were collected in late October 1995 near Outlook, Saskatchewan $\left(51^{\circ} 29^{\prime} \mathrm{N}, 107^{\circ} 03^{\prime} \mathrm{W}\right.$, elevation $518 \mathrm{~m}$ ). The collection site was a naturally-revegetated roadcut dominated by silver sagebrush, western wheatgrass (Agropyron smithii Rydb.), and needle-and-thread (Stipa comata Trin. \& Rupr.). These seeds were dried 4 weeks in the laboratory, cleaned by hand, and stored in paper bags at $4^{\circ} \mathrm{C}$ until use.

\section{Freezing Tests on 1- to 6-Week-Old Seedlings}

Seedlings in this test were grown under environmental conditions that simulated spring temperatures in southern Saskatchewan (Environment Canada 1982). Fifty seeds were sown on the surface of wet "Redi-earth" (W.R. Grace and Co. Ltd., Ajax, Ontario) media in $125 \times 100 \mathrm{~mm}$ pots and then covered with a thin layer of the media. Pots were placed in a growth chamber under 16 -hours light $\left(220 \mu \mathrm{mol} \mathrm{m} \mathrm{m}^{-2} \mathrm{sec}^{-1}\right)$ at $20 / 10^{\circ} \mathrm{C}$ day/night for 2 days to allow germination. Thirty to 40 seedlings 
were obtained in each pot. Temperatures were then set at $12 /-2^{\circ} \mathrm{C}$ for the first week, and changed weekly to $15 /-2,18 /-1,21 / 0,24 / 1$, and $27 / 2^{\circ} \mathrm{C}$ to simulate spring warming. The light period was 12.5 hours for the first week, and increased each week thereafter by one-half hour. Seedlings were watered every 3 days, and the day before freezing tests.

Seedlings of 1-, 2-, 4-, and 6-weeks of age were subjected to freezing tests. Before freezing, pots were placed in an environmental chamber at $4^{\circ} \mathrm{C}$ for 4 hours to prevent temperature shock. They were then transferred to a programmable freezing system described by Gusta et al. (1978), and held at $-2^{\circ} \mathrm{C}$ for 18 hours to allow the freezing process to reach equilibrium. The temperature was then decreased at $2^{\circ} \mathrm{C}$ hour ${ }^{-1}$. Temperatures were measured with 5 thermocouples placed $1 \mathrm{~cm}$ below the media surface in pots. Seedlings were removed at $-2,-4,-6,-8,-10,-12$, and $-14^{\circ} \mathrm{C}$, transferred to $4^{\circ} \mathrm{C}$ for 24 hours, grown 3 weeks at $20 / 15^{\circ} \mathrm{C}$ with a 12 -hour light period, and mortality determined. Control seedlings were kept at $4^{\circ} \mathrm{C}$ in darkness for the period of freezing test, but otherwise were treated the same as test seedlings. Four replicates were used for each freezing temperature, and the experiment was repeated.

\section{Freezing tests on 8- to 14-week-old seedlings}

Twenty-five seedlings pot $^{-1}$ were grown in a greenhouse $\left(20-25^{\circ} \mathrm{C}\right)$ as described above. After $6,8,10$, or 12 weeks of growth, one-half of the pots were randomly selected and transferred to a growth chamber for 2 weeks of acclimation. The remaining one-half of seedlings were grown in the greenhouse. Acclimation temperatures were $15 / 8^{\circ} \mathrm{C}$ for the first 3 days, then $10 / 5^{\circ} \mathrm{C}$ for 4 days, and $8 / 3^{\circ} \mathrm{C}$ for 7 days; light periods of $220 \mu \mathrm{mol}$ $\mathrm{m}^{-2} \mathrm{sec}^{-1}$ were $11,10.5$, and 10 hours, respectively. Seeds were planted on different dates so seedlings of different ages were subjected to freezing tests, as described above, at the same time. Freezing temperatures of $-6,-10$, and $-14^{\circ} \mathrm{C}$ were applied to 3 replicates for each treatment, and the experiment was repeated.

Another experiment was conducted to determine effects of acclimation on lethal temperatures for 50 and $95 \%$ seedling mortality $\left(\mathrm{LT}_{50}\right.$ and $\left.\mathrm{LT}_{95}\right)$. Seedlings were grown in a greenhouse for 10 weeks and then one-half of them were acclimated as described above. Acclimated and non-acclimated seedlings were exposed to freezing temperatures of $-6,-8,-10,-12,-14,-16,-18,-20$, and $-22^{\circ} \mathrm{C}$ as in the previous experiment.

\section{Freezing test of field-grown seedlings}

Silver sagebrush was seeded into cells of $2 \times 2.2 \times 10$-cm root trainers (Spencer-Lemaire Industries Ltd, Edmonton, Alberta) filled with moist "Redi-earth" media on 9 May 1996. These seedlings were grown in the greenhouse until 4 June 1996, and were thinned to $1 \mathrm{cell}^{-1}$. Seedlings were watered with a $3 \%$ solution of 20-20-20 fertilizer and then placed in a 10-cm deep pit on the campus of the University of Saskatchewan. Seedlings were watered throughout the summer when necessary. Seedlings were exposed to mean monthly temperatures ranging from 18.1 to $-21.2^{\circ} \mathrm{C}$, with absolute maximum and minimum temperatures of 34.9 and $-41.0^{\circ} \mathrm{C}$, respectively (Table 1 ).

Freezing tests were conducted on 7 November 1996, 3 March 1997, and 21 April 1997. Dates in November and March were selected because they correspond with critical times of change in cold-hardiness of plants under field conditions in Saskatchewan (Gusta and Chen 1987, Kowalenko and Romo 1998). The test in April was included because plants often begin to grow then, and also are exposed to freezing temperatures (Hou and Romo 1997). Freezing tests basically followed the same procedures described above, except that seedlings in November and March tests were transferred directly from the field into the freezing system. In April, seedlings were placed in an environmental chamber at $4^{\circ} \mathrm{C}$ for 4 hours before transferring them to the freeze chamber. Temperature in the freeze chamber was decreased at $4^{\circ} \mathrm{C}$ hour ${ }^{-1}$. Frcczing tcmperatures for November and April tests were -9, $-15,-21,-33$, and $-39^{\circ} \mathrm{C}$, whereas in March they were $-15,-21$, $-27,-33,-39$, and $-45^{\circ} \mathrm{C}$. Three replicates, each with 12 seedlings were used for each freezing temperature, and each test was repeated 3 days apart.

\section{Data analysis}

Experiments were conducted in a randomized-complete-block design (Snedecor and Cochran 1980). For 8- to 14-week-old seedlings, arcsin transformation and then factorial analysis of variance $(P \leq 0.05)$ were applied to mortality data; Tukey's honestly significant difference (HSD) was used to separate means ( $P$ $\leq 0.05$ ) (Snedecor and Cochran 1980). Untransformed data are presented. For all other tests, mortality data were subjected to probit analysis (Finney 1971, SAS Institute Inc. 1990) when applicable. Model fit was determined by Pearson Chi-square and L. R. Chi-square tests (P > 0.10)(SAS Institute Inc. 1990). Lethal temperatures for 50 and $95 \%$ mortality $\left(\mathrm{LT}_{50}\right.$ and $\left.\mathrm{LT}_{95}\right)$ along with $95 \%$ fiducial limits were determined from the model estimates. Values without overlapping fiducial limits were considered significantly $(\mathrm{P} \leq 0.05)$ different.

\section{Results}

\section{Freezing tolerance of 1- to 6-week-old seedlings}

Average $\mathrm{LT}_{50}$ and $\mathrm{LT}_{95}$ was -7.7 and $-11.1^{\circ} \mathrm{C}$, respectively for 1 - to 6-week-old seedlings (Table 2). Two-week-old seedlings

Table 1. Monthly mean, mean daily minimum, mean daily maximum, and extreme minimum and maximum temperatures to which seedlings of silver sagebrush seedlings were exposed when grown in the field from May 1996 through April 1997 on the campus at the University of Saskatchewan.

\begin{tabular}{|c|c|c|c|c|c|c|c|c|c|c|c|c|}
\hline \multirow[t]{2}{*}{ Temperature } & \multicolumn{12}{|c|}{ Month } \\
\hline & May & Jun. & Jul. & Aug. & Sep. & Oct. & Nov. & Dec. & Jan. & Feb. & Mar. & Apr. \\
\hline & $\ldots$ & 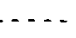 & $-1 .-$ & $-\infty-$ & $\ldots$ & $-\ldots$ & $\ldots \ldots$ & $\ldots \ldots$ & $\ldots \ldots$ & $\ldots \ldots$ & $\ldots \ldots$ & $\ldots$ \\
\hline Monthly mean & 8.4 & 15.9 & 17.6 & 18.1 & 10.2 & 2.4 & -12.6 & -19.5 & -21.2 & -11.3 & -9.8 & 2.2 \\
\hline Mean daily minimum & 2.5 & 9.4 & 11.3 & 9.7 & 4.4 & -4.4 & -17.6 & -24.5 & -27.9 & -16.6 & -15.6 & -3.4 \\
\hline Extreme minimum & -7.1 & 1.9 & 6.6 & 3.1 & -5.8 & -18.9 & -34.3 & -39.1 & -41.0 & -26.4 & -31.4 & -15.2 \\
\hline Mean daily maximum & 14.2 & 22.3 & 23.9 & 26.4 & 15.9 & 9.2 & -7.5 & -14.2 & -14.5 & -6.0 & -3.9 & 7.8 \\
\hline Extreme maximum & 24.4 & 33.0 & 32.1 & 34.9 & 24.4 & 22.7 & 9.1 & -1.1 & 4.5 & 3.3 & 11.6 & 22.0 \\
\hline
\end{tabular}


Table 2. Mean lethal temperatures $\left({ }^{\circ} \mathrm{C}\right)$ for $50\left(\mathrm{LT}_{50}\right)$ and $95 \%$ mortality (LT 95 ) of silver sagebrush seedlings that were 1-, 2-, 4-, or 6-weeks old and exposed to freezing temperatures. Means are values predicted from probit analysis; values in parentheses are $95 \%$ fiducial limits. Growth conditions are described in the text.

\begin{tabular}{|c|c|c|}
\hline Seedling age & $\mathrm{LT}_{50}$ & $\mathrm{LT}_{95}$ \\
\hline (Weeks) & \multicolumn{2}{|c|}{$\ldots \ldots \ldots \ldots$ lemperature $\left({ }^{\circ} \mathrm{C}\right) \ldots \ldots \ldots \ldots$} \\
\hline 1 & $-7.5(-6.9$ to -8.0$)$ & $-12.0(-10.9$ to -13.9$)$ \\
\hline 2 & $-8.7(-8.2$ to -9.2$)$ & $-12.9(-11.9$ to -14.5$)$ \\
\hline 4 & $-6.9(-6.5$ to -7.3$)$ & $-9.2(-8.6$ to -10.2$)$ \\
\hline 6 & $-7.7(-7.3$ to -8.1$)$ & $-10.2(-9.5$ to -11.4$)$ \\
\hline Mean & -7.7 & -11.1 \\
\hline
\end{tabular}

had the lowest $\mathrm{LT}_{50}$, but among other ages, $\mathrm{LT}_{50}$ was not different $(\mathrm{P}>0.05)$ as indicated by overlapping fiducial limits. On average $\mathrm{LT}_{95}$ was $2.8^{\circ} \mathrm{C}$ lower in 1- and 2-week than 4- and 6week-old seedlings. Changes in mortality with temperature were more gradual in younger than older seedlings, as indicated by slopes of fitted curves from probit analysis (Fig. 1). Estimated slopes and fiducial limits in the probit scale for 1-, 2-, 4-, and 6week-old seedlings were $7.9 \pm 0.9,9.8 \pm 1.1,13.5 \pm 1.9$, and 13.4 \pm 1.8 , respectively.

\section{Freezing tolerance of 8- to 14-week-old seedlings}

Mortality of silver sagebrush was influenced by the interacting effects of seedling age, acclimation, and freezing lemperatures. Death of seedlings under the same growing and freezing conditions was greater $(P<0.05)$ in younger than older seedlings (Table 3); mortality was generally greater in non-acclimated versus cold acclimated seedlings (Table 3 ). For example, mortality after exposure to $-10^{\circ} \mathrm{C}$ was $100 \%$ in 8 -week-old seedlings, but $29.3 \%$ in 14-week-old seedlings that were acclimated. Exposure of acclimated, 8-week-old seedlings to $-14^{\circ} \mathrm{C}$ killed $54.7 \%$ of the plants, compared to nearly no mortality in older seedlings that were acclimated. Except for 8-week-old seedlings, virtually no non-acclimated seedlings survived $-14^{\circ} \mathrm{C}$, while death of acclimated seedlings was nearly nil.

In the separate experiment using 12-week-old seedlings, $\mathrm{LT}_{50}$ and $\mathrm{LT}_{95}$ for greenhouse-grown seedlings were -8.6 and $-11.5^{\circ}$ $\mathrm{C}$ (95\% fiducial limits are -8.1 to -9.1 and -10.6 to $-13.0^{\circ} \mathrm{C}$, respectively) compared to -17.1 and $-19.8^{\circ} \mathrm{C}(-16.5$ to -17.6 and -19.1 to $-21.0^{\circ} \mathrm{C}$, respectively) for acclimated seedlings (Fig. 2).

\section{Freezing tolerance of field-grown seedlings}

On 7 November 1996 , only $6.9 \pm 5.5 \%$ of seedlings died after exposure to $-39^{\circ} \mathrm{C}$, the lowest temperature used on this date (Fig. 3 ). Freezing tolerance of seedlings remained high over winter; seedling mortality after exposure to -39 and $-45^{\circ} \mathrm{C}$ averaged 5.6 $\pm 4.1 \%$ on 3 March 1997. In November 1996 and March 1997, $\mathrm{LT}_{50}$ and $\mathrm{LT}_{95}$ could not be determined because seedling survival over the range of freezing temperatures was high. By comparison, cold-hardiness of seedlings dropped sharply through March and April, and no seedlings survived temperatures lower than $-15^{\circ} \mathrm{C}$ on 21 April 1997. In April $\mathrm{LT}_{50}$ and $\mathrm{LT}_{95}$ averaged -15.6 and $-19.3^{\circ} \mathrm{C}$ (95\% fiducial limits are -13.5 to -21.9 and -17.0 to $<-45.0^{\circ} \mathrm{C}$, respectively).

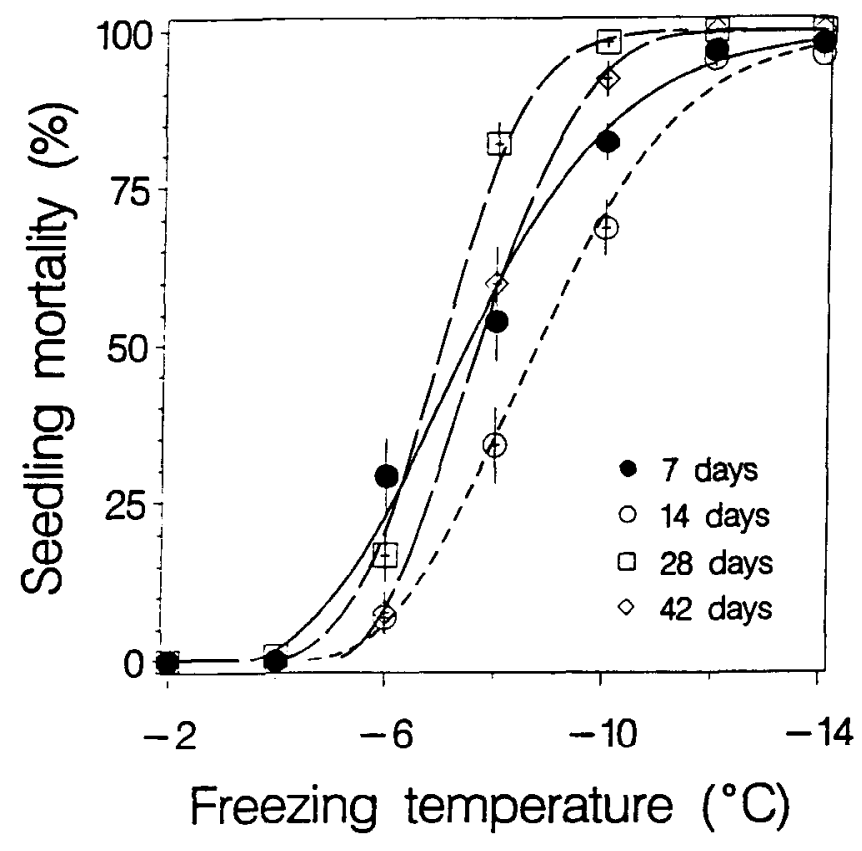

Fig. 1. Mortality of silver sagebrush seedlings after exposure to freezing temperatures at 1-, 2-, 4-, or 6-weeks of age. Growth conditions are described in the text. Each point is the mean \pm SE of 8 replicates. Where vertical bars are lacking, the standard error is smaller than the symbol. Lines are predicted responses based on probit analyses.

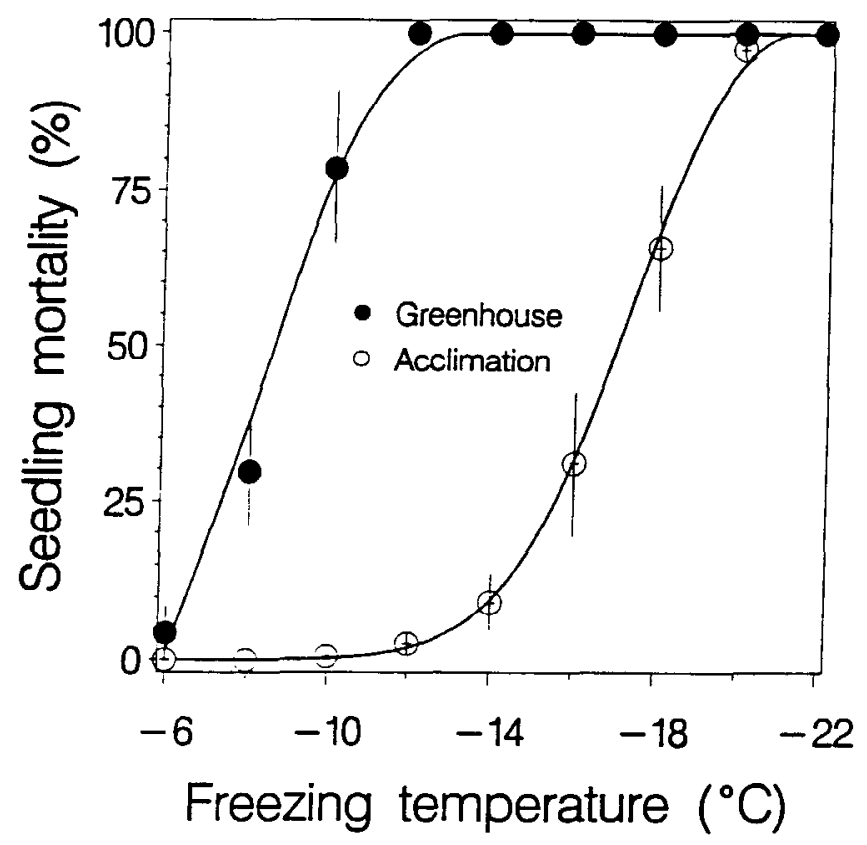

Fig. 2. Effect of cold acclimation on mortality of 12 -week old silver sagebrush seedlings that were exposed to freezing temperatures. Growth conditions are described in the text. Each point is the mean \pm SE of 6 replicates. Where vertical bars are lacking, the standard error is smaller than the symbol. Lines are predicted responses based on probit analyses. 
Table 3. Effect of cold acclimation on mortality (\%) of 8- to 14-week old silver sagebrush seedlings after exposure to freezing temperatures. Growth conditions are described in the text. Each value is the mean of 6 replicates. Means with similar letters are not significantly different using Tukey's HSD (P $\leq$ 0.05).

\begin{tabular}{|c|c|c|c|c|c|c|c|c|}
\hline \multirow{3}{*}{ Seedling age } & \multicolumn{4}{|c|}{ Cold acclimated } & \multicolumn{4}{|c|}{ Non-acclimated } \\
\hline & \multicolumn{4}{|c|}{ Freezing temperature $\left({ }^{\circ} \mathrm{C}\right)$} & \multicolumn{4}{|c|}{ Freezing temperature $\left({ }^{\circ} \mathrm{C}\right)$} \\
\hline & Control & -6 & -10 & -14 & Control & -6 & -10 & -14 \\
\hline \multicolumn{9}{|l|}{ (weeks) } \\
\hline 8 & $0.0 \mathrm{a}$ & $0.0 \mathrm{a}$ & $8.0 \mathrm{~b}$ & $54.7 \mathrm{f}$ & $0.0 \mathrm{a}$ & $45.3 \mathrm{e}$ & $100.0 \mathrm{~h}$ & $100.0 \mathrm{~h}$ \\
\hline 10 & $0.0 \mathrm{a}$ & $0.0 \mathrm{a}$ & $0.7 \mathrm{a}$ & $1.3 \mathrm{a}$ & $0.0 \mathrm{a}$ & $1.3 \mathrm{a}$ & $70.7 \mathrm{~g}$ & $100.0 \mathrm{~h}$ \\
\hline 12 & $0.0 \mathrm{a}$ & $0.0 \mathrm{a}$ & $0.0 \mathrm{a}$ & $0.7 \mathrm{a}$ & $0.0 \mathrm{a}$ & $0.0 \mathrm{a}$ & $38.6 \mathrm{~d}$ & $100.0 \mathrm{~h}$ \\
\hline 14 & $0.0 \mathrm{a}$ & $0.0 \mathrm{a}$ & $0.0 \mathrm{a}$ & $0.0 \mathrm{a}$ & $0.0 \mathrm{a}$ & $0.0 \mathrm{a}$ & $29.3 \mathrm{c}$ & $98.7 \mathrm{~h}$ \\
\hline
\end{tabular}

\section{Discussion}

Freezing tolerance of temperate, perennial plants usually increases after a period of exposure to low temperatures (Levitt 1980, Gusta and Chen 1987, Guy 1990). This study demonstrated an increase of more than $8^{\circ} \mathrm{C}$ in freezing tolerance of 12 -weekold silver sagebrush seedlings following cold acclimation for 2 weeks. Additional acclimation can further increase freezing tolerance, as indicated by low seedling mortality after freezing tests in November and March. Increased mortality during freezing tests in April indicates seedlings lost cold-hardiness rapidly as temperatures rose and day length increased in spring.

Adjustment of freezing tolerance during cold acclimation in silver sagebrush is also apparently related to seedling age. After similar acclimation conditions, more than $50 \%$ of 8 -week-old seedlings died following exposure to $-14^{\circ} \mathrm{C}$, compared to near $0 \%$ in older ones. Higher freezing tolerance was found in younger

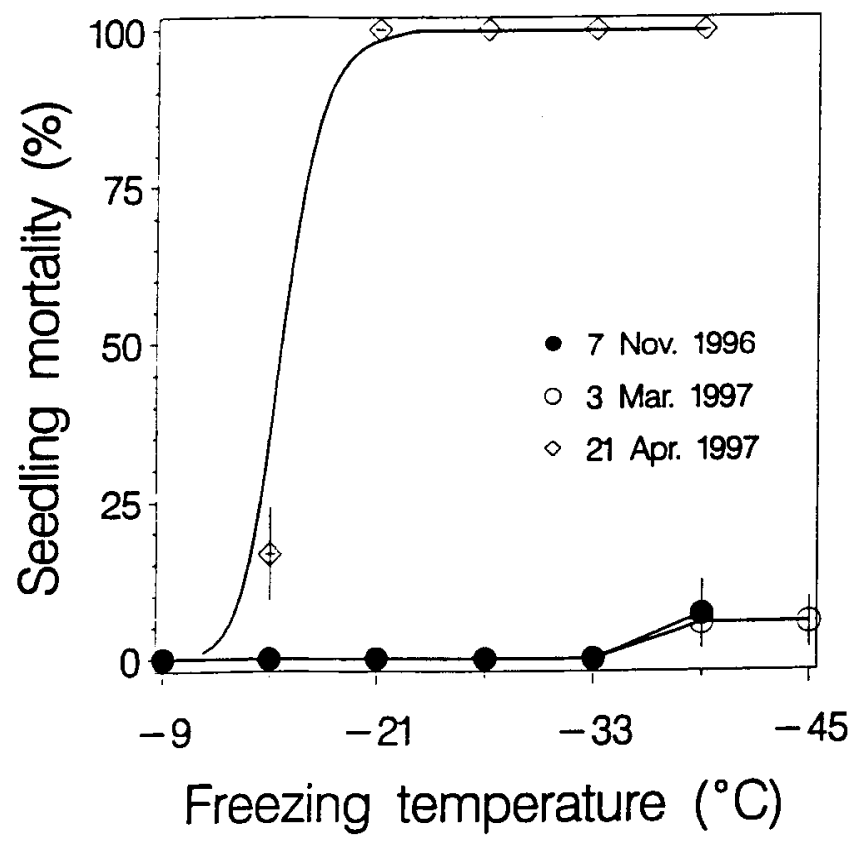

Fig. 3. Mortality of silver sagebrush seedlings that were grown in the field and then exposed to freezing temperatures. Growth conditions are described in the text. Seedling mortality values on 7 November and 3 March overlap at $-9,-15,-21,-27$, and $-33^{\circ} \mathrm{C}$. Each point is the mean $\pm S E$ of 6 replicates. Where vertical bars are lacking, the standard error is smaller than the symbol. Lines are predicted responses based on probit analyses. than older seedlings in winterfat Ceratoides lanata (Pursh) J. T. Howell) that were 1 to 4 weeks of age (Hou and Romo 1997). As seedlings grow, they develop differentiated vascular vessels that hold free water. Formation of ice crystals in the vessels may damage tissues (Olien 1964, Gusta and Chen 1987), which partly explains greater mortality in older than younger seedlings after freezing. In this study, $\mathrm{LT}_{50}$ for 1- to 6-week-old seedlings of silver sagebrush did not show a clear association of freezing tolerance with seedling age and temperatures during growth. However, some evidence indicates greater freezing tolerance may exist in younger than older silver sagebrush seedlings as shown for winterfat (Hou and Romo 1997). First, $\mathrm{LT}_{95}$ for 1- and 2 week-old scedlings was $2^{\circ} \mathrm{C}$ lower than 4- to 6-week-old seedlings, implying younger seedlings may survive exposure to temperatures $-10^{\circ} \mathrm{C}$ or lower better than older ones. Second, changes in mortality with temperature were more gradual in younger than older seedlings. Younger seedlings might consist of individuals at slightly different stages of tissue differentiation. Some seedlings with small undifferentiated cells might be more freezing tolerant, compared to those with vascular vessels, because they might escape injury caused by ice formation (Olien 1964, Gusta and Chen 1987). For older seedlings, a single event that freezes free water in the veins, may be responsible for nearsynchronous mortality.

In 8- to 14-week-old seedlings, freezing tolerance increased as plants grew. Increased freezing tolerance may be attributed to lignification of cell walls and development of lateral meristematic regions (Levitt 1980, Gusta and Chen 1987, Guy 1990). Lignified cell walls may increase the ability of plant tissues to withstand pressure from growing ice crystals. Lateral meristematic regions produce lateral buds and roots, assisting recovery of plants from freezing damage.

Changing freezing tolerance with seedling growth is likely not straightforward in silver sagebrush. Newly germinated seedlings with undifferentiated cells may have relatively high freezing tolerance. Freezing tolerance may decrease as tissues differentiate, then increase as lignification and lateral meristematic regions develop. Further increases in freezing tolerance are not expected without cold acclimation, but as shown the increase in cold-hardiness was substantial with acclimation.

In conclusion, $\mathrm{LT}_{50}$ and $\mathrm{LT}_{95}$ for 1- to 6-week-old seedlings indicate that young silver sagebrush plants can be damaged or killed when temperatures drop to about -7 and $-13^{\circ} \mathrm{C}$, respectively. On the Canadian Prairies temperatures within this range often occur during April and early May (Environment Canada 1982, see Hou and Romo 1997), months when most silver sagebrush seedlings emerge (Romo unpub. data). Sudden reduction of ternperatures in autumn may also damage seedlings, as evidenced by 
$\mathrm{LT}_{50}$ of $-8.6^{\circ} \mathrm{C}$ and $\mathrm{LT}_{95}$ of $-11.5^{\circ} \mathrm{C}$ for 12 -week-old seedlings that were not cold acclimated. Since the potential of developing freezing tolerance is greater in older than younger seedlings, silver sagebrush seedlings that germinate early in growing season may survive winter better than those germinating later. Under normal circumstances, temperatures on the Canadian Prairies may not threaten survival of silver sagebrush seedlings experiencing their first winter, as winter temperatures seldom get below the lowest temperatures $\left(-39\right.$ and $\left.-45^{\circ} \mathrm{C}\right)$ tested in this study (Environment Canada 1982, Gusta and Chen 1987), especially under snow. Poor emergence (Romo unpub. data) and other factors are likely more important in controlling establishment of silver sagebrush seedlings than freezing temperatures.

\section{Literature Cited}

Barrett, M. W. 1979. Evaluation of fertilizer on pronghorn winter range in Alberta. J. Range Manage. 32:55-59.

Clarke, S.E. 1930. Pasture investigations of the short grass prairie of Saskatchewan and Alberta. Sci. Agr. 10: 732-749.

Coupland, R. T. 1950. Ecology of Mixed Prairie in Canada. Ecol. Monogr. 20:271-315.

Finney, D. J. 1971. Probit analysis. $3^{\text {rd }}$ ed. Cambridge University Press. London.

Environment Canada, Atmospheric Environmental Service. 1982. Canadian climate normals (1951-1980), temperature and precipitation (prairie provinces). Ottawa, Canada.

Gusta, L. V. and T. H. H. Chen. 1987. The physiology of water and temperature stress. pp. 115-150. Wheat and wheat improvement Agron. Monogr. No. 13. ASA-CSSA-SSSA, Madison, Wisc.

Gusta, L. V., M. Boyachek, and D. B. Fowler. 1978. A system for freezing biological materials. Hort. Sci. 13:171-172.
Guy, C. L. 1990. Cold acclimation and freezing stress tolerance: Role of protein metabolism. Annu. Rev. Plant Physiol. 41:187-223.

Hou, J. Q. and J. T. Romo. 1997. Growth and freezing tolerance of winterfat seedlings. J. Range Manage. 50:165-169.

Howard, G. S., G. E. Schuman and F. Rauzi. 1976. Growth of selected plants on Wyoming surface-mined soils and flyash. J. Range Manage. 30:306-310.

Kowalenko, B.L. and J.T. Romo. 1998. Defoliation and cold-hardiness of northern wheatgrass. J. Range Manage. 51:63-68.

Levitt, J. 1980. Responses of plants to environmental stresses, No. I. Chilling, freezing, and high temperature stresses. $2^{\text {nd }}$ ed. Academic Press. New York, N.Y.

Mitchell, G.J. and S. Smoliak. 1971. Pronghorn antelope range characteristics and food habits in Alberta. J. Wildl. Manage. 35: 238-250.

Olien, C. R. 1964. Freezing processes in the crown of 'Hudson' barley, Hordeum vulgare (L., emend. Lam.) Hudson. Crop Sci. 4:91-95.

Pyke, D. A. and S. Archer. 1991. Plant-plant interactions affecting establishment and persistence on revegetated rangeland. J. Range Manage. 44:550-557.

SAS Institute Inc. 1990. SAS/STAT user's guide. Version $6,4^{\text {th }}$ ed. SAS Institute Inc., Cary, N.C.

Snedecor, G. W. and W. C. Cochran. 1980. Statistical methods. The Iowa State Univ. Press, Ames, Iowa.

Walser, R. H., D. J. Weber, E. D. McArthur and S. C. Sanderson. 1990. Winter cold hardiness of seven wildland shrubs. pp. 115-118. In: E. D. McArthur, E. M. Romney, S. D. Smith and P. T. Tueller (compilers). Proc. Symp. on Cheatgrass invasion, shrub die-off, and other aspects of shrub biology and management. USDA Forest Serv. Gen. Tech. Report INT-276.

White, R. S. and P. O. Currie. 1983. The effects of prescribed burning on silver sagebrush. J. Range Manage. 36:611-613.

Young, J. A. and R. A. Evans. 1989. Reciprocal common garden studies of the germination of seeds of big sagebrush (Artemisia tridentata). Weed Sci. 37:319-325. 